\begin{abstract}
This paper is a study of the process by which employers in five relatively low-wage British firms fill vacancies. It studies the determinants of the number and quality of applicants, the way in which these applicants are selected for interviews and offered jobs. The main conclusions are that the number of applicants is relatively small, the monetary and non-monetary aspects of jobs are important determinants of the number of applicants for jobs, but that firms do eventually fill virtually all vacancies. Non-employed job applicants have more difficulty in getting a job interview than those who are currently employed but, once interviewed, do not appear to face any further difficulties in getting employment.
\end{abstract}

This paper was produced as part of the Centre's Industrial Relations Programme 


\section{Pretty Vacant: \\ Recruitment in Low-Wage Labour Markets}

Alan Manning

March 1999 
Series Editor: Graham Ingham

Published by

Centre for Economic Performance

London School of Economics and Political Science Houghton Street

London WC2A 2AE

C C A. Manning, submitted December 1998

ISBN 0753012685

Individual copy price: $£ 5$ 


\section{Pretty Vacant: \\ Recruitment in Low-Wage Labour Markets}

Alan Manning

Introduction

1. The Data 2

$\begin{array}{ll}1.1 \text { general } & 2\end{array}$

1.2 data description 2

1.3 characteristics of the vacancies 3

1.4 recruitment methods 4

1.5 outcomes 4

2. Modelling Outcomes 5

2.1 the number of applicants 5

$\begin{array}{ll}2.2 \text { the quality of applicants } & 7\end{array}$

2.3 the number of interviews and offers 8

3. The Selection Procedure 8

4. Conclusions 10

Tables $\quad 11$

Figure $\quad 20$

Appendix 21

References $\quad 22$

The Centre for Economic Performance is financed by the Economic and Social Research Council 


\section{Acknowledgements}

The data used in this paper is drawn from a wider project on "Recruitment and Retention in LowWage Labour Markets" funded by the Joseph Rowntree Foundation. I would like to thank Donna Brown for her help in collecting and setting-up this data and John Knight for his detailed editorial comments.

Alan Manning is a Professor of Economics at the London School of Economics and a member of the Centre for Economic Performance. 


\title{
Pretty Vacant: Recruitment in Low-Wage Labour Markets
}

\author{
Alan Manning
}

\section{Introduction}

There is an enormous literature on job search by the unemployed and the duration of spells of unemployment. But, rather little is known about the other side of the matching process, the filling of vacancies. For example, Devine and Kiefer (1991), in their encyclopaedic review of search models of the labour market, can only find nine studies of vacancies to discuss as compared to literally hundreds of studies on unemployment durations and job search by the unemployed. The reason for this neglect of vacancies is that detailed information about them is not normally collected on a systematic basis ${ }^{1}$. The few studies there are tend to rely on one-off datasets. This paper is no exception. It uses data collected over a period of three months from five firms operating in relatively low-wage sectors of the British economy.

Most existing studies of vacancies focus either on the outcome of the recruitment process measured as vacancy durations (eg Beaumont, 1978; Roper, 1988; van Ours, 1989; van Ours and Ridder, 1992, 1993), vacancy rates (Holzer, 1994) or the inputs into the recruitment process by employers (Barron and Bishop, 1985; Barron, Bishop and Dunkelberg, 1985). In contrast, the emphasis in this paper is on the process by which vacancies are filled. It examines the determinants of the number and quality of job applicants, the number of interviews and offers made. The paper also analyses the way in which employers select workers from among the pool of job applicants. There are a few papers which consider some of these issues (eg van Ours and Ridder, 1993, on the determinants of the number of job applicants) but, for the most part, there is little existing econometric evidence on the issues we model here. There are two main areas in which we might hope to improve our understanding of labour markets by such a study of the recruitment process.

First, we should be able to shed some light on the nature of the employment 'problem' in low-wage labour markets and, hence, to get some idea of the likely effectiveness of some recent government policy initiatives ${ }^{2}$. For example, if unemployment is largely involuntary (perhaps because of efficiency wage effects) then we might expect to see large queues of workers for our jobs even though these are jobs at or near the bottom end of the labour market. In this case, policies to price workers back into employment might be most effective. On the other hand, if vacancies have rather few applicants this suggests that it is the supply of workers that is the constraint on employment and policies to 'make work pay' might be more effective in reducing unemployment.

Secondly, as our dataset has information on all the applicants to the vacancy and not just those who were successful, we can say something about the process by which employers make hiring decisions. In particular, we are interested in the extent to which employers reject

1 Indeed, there are often problems in defining exactly what a vacancy is. NBER (1966) essentially concluded, after more than 500 pages, that a coherent definition of a vacancy was impossible to provide.

2 From the work of Gregg and Wadsworth (1996) and Gregory and Jukes (1997) we know that the unemployed typically go into the sort of jobs we are studying. 
unemployed job-seekers in favour of employed ones as has been suggested, for example, by Layard, Nickell and Jackman (1991), Blanchard and Diamond (1994), and van Ours and Ridder (1995). There is strong circumstantial evidence of this practice (eg Meager and Metcalf (1987, 1996)) but little in the way of more formal evidence.

The plan of the paper is as follows. In the next section, we describe the data. We then outline a framework for thinking about the process by which vacancies are filled and analyse the determinants of the number and quality of applicants and the process by which the vacancies are filled. Finally, we present some evidence on the way in which employers choose from the pool of job applicants.

Because of the nature of the sample, our conclusions can have no pretence to generality. In spite of this we think some of the findings are interesting and do contribute to our understanding of the workings of low-wage labour markets. Our main findings are that:

- the average number of applicants per vacancy is slightly under three;

- the number of applicants is influenced by the wage offered and non-wage aspects of jobs like the location and accessibility of the workplace;

- employers are able to fill the vast majority of their vacancies suggesting that the number of applicants plays a role only in widening the choice (and, hence, quality) of applicants;

- job applicants who are not currently employed do appear to be at a disadvantage in getting a job interview but, conditional on having made it to interview, appear not to suffer any further disadvantage in getting a job offer.

\section{The Data}

\section{1 general}

The data are drawn from a wider project on "Recruitment and Retention in Low-Wage Labour Markets". The general aim of this project was to obtain high-quality information on workers in low-wage sectors. Five companies agreed to participate in the study by providing administrative data and also distributing and collecting questionnaires on various aspects of the company's activities. The identity of the companies will be referred to here by their activity: a restaurant, a hotel, a leisure company, a supermarket and a low-wage manufacturing sector.

Obviously the companies were not chosen randomly and, given this fact, there might be some concerns about their representativeness or motives. Their interest in the project was due to the fact that we could offer research that they generally did not have the resources to do (for example, we could compare the company workforce to workers in its specific industry using the Labour Force Survey). Each company was provided with a report specific to it containing this type of information but it was made clear that the academic output of the project would be as we saw fit.

\section{2 data description}

This paper analyses the information on the recruitment process that was collected as part of the project. For each vacancy that occurred in each participating workplace in the sample period (the Autumn of 1996), the responsible manager was asked to provide some general information about it. These "top-sheets" varied slightly from company to company (as they were tailored to the specific structure of the company concerned) but generally provided information on the package 
offered in terms of wage and non-wage benefits, the recruitment methods used and their cost, the date at which the vacancy occurred, the number of vacancies, the number of applicants, interviews and offers, and the date on which it was filled. This obviously requires some effort on the part of the manager so we would not expect $100 \%$ compliance rates. Table 1 shows the number of new starts from the vacancy data compared to the number of new recruits in the sample period from the administrative data. For the branches that participated, the response rates are good but there were a number of branches which did not co-operate at all.

In addition, we asked the responsible manager to keep a record of each applicant for the job, detailing the date he or she applied, some personal characteristics, the date of interview, the date an offer was made, with reasons for rejection given at each stage. Figure 1 provides a stylised representation of the application process and the numbers of individuals at each stage.

In total, we have information on 122 vacancy events comprising 425 vacancies. Because Four of these did not provide any information beyond the barest description of the vacancy, they are dropped from the sample for the analysis. $47 \%$ of the vacancy events are for a single worker with a further $22 \%$ being for two workers though we do have one situation where the employer sought to fill 16 vacancies.

\section{3 characteristics of the vacancies}

Table 2 provides summary statistics on the vacancies in our sample. Managers were given an option to report either a single starting wage or a maximum and a minimum. Only 16 took this latter course, the average gap between the maximum and minimum starting rates being $19 \%$. For the analysis below we used a geometric average of the minimum and maximum starting wages as a measure of the average and also include a dummy variable to denote whether there was variation in the starting wage. The average wage is $£ 3.53$ per hour which is somewhere between the fifteenth and twentieth percentile in the overall wage distribution (using the LFS).

Average wages paid do not mean much without considering the alternatives that workers might expect to get. We have a number of sources of information on alternative wages. First, managers were asked to list up to five main competitors in the labour market and record the wage that they paid. We took the geometric average of these to compute a measure of competitors' wages. We also got estimates of average hourly wages in the company's industry in the relevant travel-to-work area from the New Earnings Survey. Finally, we asked managers to state whether they thought they paid above or below the going rate in their labour market. These answers were on a scale ranging from 1 (well below average) to 5 (well above average).

The answers from the self-reported wages, competitor wages and relative wage performance are more or less consistent. For example, Table 3 presents the wage relative to those of the competitors for each of the wage performance categories: the relative wage changes monotonically in the direction we would expect. The performance of the alternative wage derived from the NES was less satisfactory. The correlation between these measures of alternative wages and those reported by the companies themselves was only 0.4 . Given that a relatively small set of employers replied to the question about competitors' wages, we use only the self-reported relative wage performance in what follows.

We might be also concerned about the extent of exogenous variation in wages in our data. Differences in the wage policies pursued by our companies can provide some reassurance on this. Some of our companies operate a national pay policy with little or no regional variation in wages while others leave pay determination entirely in the hands of local managers. We can see the consequences of this in our data. The restaurant leaves pay policy in the hands of its local managers, and the correlation of the self-reported relative pay measure and the average regional 
wage is 0.04 . On the other hand, the supermarket and the hotel chain both have a national pay policy with limited regional variation so that their pay is relatively good in low-wage regions and relatively bad in high-wage regions: for the supermarket the correlation between relative pay and the average regional wage is -0.9 while for the hotel it is -0.65 .

We also collected information on how long workers had to wait until they could expect a rise in the wage and the size of the rise they might then expect to get. On average workers could expect to wait 21 weeks for a pay rise, which was then of the order of $6 \%$ (as one might expect there is a negative correlation between the waiting period and the size of the rise).

It is possible that non-wage characteristics of the job are also important in determining the attractiveness of jobs. We have information on fringe benefits offered and on the location of the workplace. Table 2 reports the fraction of starters getting tips, bonuses and possibilities of overtime. Table 2 also reports the fraction of workplaces that are centrally located, accessible by public transport or with transport provided by the company. We also have some information on the specific job for which the vacancy is being posted. The majority of the vacancies are for 'unskilled' jobs where qualifications are not required but we have created a dummy variable where specialist skills are needed: only $8 \%$ of vacancies fall into this category.

\section{4 recruitment methods}

We also collected information on the recruitment methods used to fill vacancies. We asked about five different methods: notifying the job centre, placing an advert in a local paper, using a private employment agency, using existing workers and approaching workers already known to the employer. Approaches to existing staff and job centres are the most frequently used methods, and a third use newspaper adverts and direct approaches to specific workers (Table 2). Only a small minority used a private employment agency: this is an expensive option and not one used for most of the relatively unskilled jobs that comprise the bulk of our sample.

\section{5 outcomes}

We are interested in the extent to which the characteristics of vacancies described above affect the ability to fill vacancies and the time it takes to do so. A natural first stage is to look at the extent to which these factors affect the number and quality of applicants. Table 2 summarises the number of applicants and number of applicants per vacancy. In general, the number of applicants per vacancy is quite small, less than three. This number could be compared to the 6.6 applicants per opening that Holzer, Katz and Krueger (1991) report for low-wage jobs in the US. Turning to the next stage of the recruitment process, we present summary information on the number of interviews and the number of offers made. On average there are 1.4 interviews per vacancy and 0.86 offers. This indicates that the employers are eventually managing to fill most of their vacancies. 


\section{Modelling Outcomes}

\section{1 the number of applicants}

Perhaps the most commonly used framework for thinking about the process of filling vacancies is the matching approach pioneered by Diamond (1982) and Pissarides (1990). In this approach vacancies and workers wander around bumping into each other and forming a match if it is mutually beneficial to do so. If a match is not formed the pair are assumed to be unable to return to each other (the assumption of no recall).

While this approach has generated very useful insights into the dynamics of unemployment in the economy as a whole it may not be a very realistic description of the way in which vacancies actually get filled. Ridder and van Ours (1992,1993), using Dutch data, conclude that the duration of vacancies are better modelled as an application period in which a number of applications flow into the firm and a selection period when the employer picks the best from among the applicants. They conclude that vacancy durations are determined more by the length of the selection process than by the time it takes for applicants to contact the firm. Van Ours and Ridder do not suggest an explanation of why, immediately following the advertising of a vacancy, there is a very rapid flow of applicants to the firm which then tails off. One plausible explanation for this has been proposed by Coles and Smith (1994). They suggest that a more realistic view of the matching process is that job-seekers are normally aware of where vacancies will be advertised (eg the job centre or local newspapers) and that the posting of a vacancy will result in a very rapid inflow of applicants. The employer will then choose the most suitable from among this list: if it fails to find anyone suitable then it has to wait for an interested (and suitable) new job-seeker to see the vacancy ${ }^{3}$. In this framework the time to fill a vacancy is primarily determined by the time it takes to select a suitable candidate.

Consider how we might capture these ideas more formally. Assume that, at any moment, there is a pool of job-seekers who would be prepared to work for the firm and who would be aware of a vacancy if it were advertised. If there is no vacancy, then these individuals will have no opportunity to get employment but, as soon as there is a vacancy, they will apply. This pool of potential applicants will not be constant: individuals leave the pool because, for example, they get a better job elsewhere or because their personal circumstances change. Workers will enter the pool for similar reasons. At any moment there will be a stock $A$ of individuals who are interested in the job and aware of it. $A$ will be a random variable: let us denote the steady-state probability that there are A individuals in the pool by $\mathrm{f}_{A}$.

To derive $f_{A}$ we need to make some assumption about the rate at which individuals enter and leave the pool of interested and aware job-seekers. Suppose that individuals join the pool of potential applicants at a rate $r$ and leave it at a rate $d$. This problem is well-known in queuing theory (see, for example, Gross and Harris, 1974) and the steady-state distribution of the number of people in the pool, $A$, is given by a Poisson distribution of the form:

3 Gregg and Petrongolo (1997) use this framework to analyse the aggregate matching function for the UK concluding that it does a better job in explaining the data than the traditional DiamondPissarides specification.

4 The argument behind the derivation of (1) is presented in an Appendix. 


$$
f_{A} \quad \frac{e^{\delta \mu} \cdot \mu^{A}}{A !}
$$

where $\mu=r / d$. The expected number of people in the pool is given by $\mu$ which is what we would expect given that $\mu$ is the ratio of the arrival rate to the separation rate. What factors would we expect to determine $\mu$ ? It seems sensible to assume that it will be determined partly by the utility offered by this job (which will have both monetary and non-monetary components) relative to what is available in the rest of the labour market and factors which affect the awareness of the vacancy to potential applicants. These are the variables that we will attempt to use to explain the number of applicants in the empirical analysis.

Given the theoretical framework sketched above, the most appropriate statistical model for the number of applicants would seem to be a Poisson regression model. In this case we operationalise (1) by assuming that:

$$
\mu \quad \exp (\beta) x \%)
$$

where $x$ is a set of relevant characteristics and $e$ is an error. It is convenient and standard to assume that $\exp (e)$ has a gamma distribution. It is then well-known that the distribution of the number of applications will have a negative binomial distribution (for example see Greene, 1997, p.940). The Poisson model is a special case of this one but, in our data, the restriction implied by the Poisson model is always very strongly rejected, so the results are not reported. The results of estimating this model for the number of applicants are presented in Table 4.

The first column presents a basic specification in which the wage offered is measured by the self-assessed wage performance (assumed to be a cardinal measure). Several findings stand out. First, the location of the firm is important in determining the number of applicants. Workplaces with a central location or accessible by public transport have larger numbers of applicants than those in less accessible locations. Providing assistance with transport to work does not seem to increase the number of applicants but it is likely that there is a serious endogeneity problem here as only those establishments with particular problems in this area are likely to provide this assistance.

Secondly, the wage offered relative to competitors does seem to increase the number of applicants, though the estimated coefficient only has a t-statistic of 1.7. Jobs that require specialist skills attract significantly fewer applicants than others. This is consistent with the finding that vacancies for skilled workers are often harder to fill than those for less-skilled jobs. The recruitment methods do not seem to make much difference, there being only weak evidence that advertising in a newspaper increases the number of job applicants. Approaching individuals known to the employer seems to be associated with having fewer applicants but this may be because employers doing this are targeting specific individuals and do not make any attempt to attract job applicants from a wider pool.

The second column presents a more parsimonious version of the first column with the variables whose coefficients were insignificant at conventional levels being dropped. One variable not included in the original specification that does seem to be an important determinant of the number of applicants is the number of vacancies. The third column reports estimates of the preferred specification which includes this variable. It has little impact on the coefficients on the other variables with the exception of the newspaper advertisement variable. There are a number of reasons why the number of vacancies might raise the number of job applicants. First, a firm 
with more vacancies to fill might be expected to put more effort into its recruitment process, though we might expect that our variables on recruitment methods would pick this up. Secondly, it may be that individuals are more likely to apply if they see that many jobs are being advertised. There is some cost (albeit small) involved in applying for a job, and it may be the case that some people do not apply for jobs they think they have no chance of getting.

Columns 4-6 experiment with looking at the impact of the wage contract offered on the number of applicants. In the fourth column we break up the wage performance variable (which is really only an ordinal measure) into dummy variables for paying above or below the average. The estimated coefficients have the expected signs though those who pay above average do not appear to have significantly higher numbers of applicants. The fifth column includes a dummy variable for whether there is any variation in the starting-wage: vacancies where this is the case do have significantly higher numbers of job applicants. The sixth column includes other measures of the wage package: the availability of fringe benefits, the expected time to the first pay increase and its expected size (note that the sample size falls as these variables are not available for all vacancies). None of these variables appears to have a significant influence on the number of job applicants.

Columns 7-8 look at the determinants of the number of applicants who are currently employed and those who are not currently employed. Some of the results are similar: wage performance seems to have a similar impact, though the estimated coefficient is not significantly different from zero in either equation. But other results are rather different: variation in wages, the availability of public transport, a specialist job and the number of vacancies seem to have a much larger effect on the number of non-employed job applicants, while a central location is more important for employed applicants.

Overall, how should these results inform one's view of the way the labour market works? They suggest that the terms and conditions offered have an important impact on the number of applicants. This seems to be the case both for applications from those currently in employment and those currently out of work. It is perhaps not so surprising that applications from employed workers are influenced by the terms and conditions offered but the results for applications from those out of work deserve more discussion. The facts that these jobs attract relatively small numbers of applicants and the number of applications are sensitive to wages offered suggest that these jobs are not so much better than alternatives that all non-employed workers want all jobs. This suggests that extreme notions of involuntary unemployment in which wages are above marketclearing levels are not supported by the data. One might be tempted to conclude that policies to improve terms and conditions like a minimum wage will increase the number of applicants for these jobs. That might be the case (Holzer, Katz and Krueger, 1990, do present some US evidence on this) but the overall effect on employment depends on whether the supply of vacancies increases or decreases as a result, something on which our study can shed no light. The finding that getting to work is an important consideration is consistent with some other evidence. For example, Manning and Thomas (1997) find that the unemployed with access to motor transport are more likely to get a job than others. However, little attention is paid in the literature to these spatial issues: perhaps, they deserve further research.

\section{2 the quality of applicants}

How do the variables we have used above influence the average quality of applicants? We have information on a number of applicant characteristics: their sex, their age, whether they have relevant experience, whether they are currently employed, and whether they have been previously employed by the company. Descriptive statistics on these variables are presented in Table 2. 
While it is clear that some of these characteristics are associated with higher quality, with others (eg sex) it is not clear. We present evidence below about which characteristics employers seem to prefer in selecting applicants for interview: we can then use a revealed preference argument to say which characteristics the employer seem to value.

The results of models for the proportion of applicants with different characteristics are given in Table 5. The most striking feature of these results is the lack of any systematic influence of any of the explanatory variables: the characteristics of applicants do not seem to be very sensitive to the characteristics of the vacancy.

\section{3 the number of interviews and offers}

Table 6 looks at the determinants of the number of interviews conducted and job offers made. In modelling these outcomes we can use the same model as we used to model the number of applicants (i.e. the model summarised in (1) and (2)) with $A$ now referring not to the total number of applicants but the number of applicants whom the employer wants to interview or to whom they would like to make an offer. The first column includes the variables that were previously found to be significant in the determination of the number of applicants. The only explanatory variable that is significant is the number of vacancies and this variable becomes more significant as we change the dependent variable from interviews to offers. The explanation is simple: virtually all of our sample eventually fill all their vacancies and the only impact of an increased applicant pool is to give the employer a wider choice. We do not have a large number of vacancies in which the pool of applicants is so bad in the eyes of the employer that the job is left empty.

Columns 3 and 4 present a slightly different approach to the determinants of the number of interviews and offers where we look at the choice conditional on the size and average quality of the applicant pool. The number (but not the quality) of applicants does seem to exert a significant influence over the number of interviews, but a smaller influence over the number of offers. The number of vacancies is again the most important variable explaining the number of offers.

\section{The Selection Procedure}

In this section we present information on the way in which applicants are selected by employers to fill vacancies. The managers were asked to record, for each vacancy, basic information about each applicant. We are interested in how the characteristics of an applicant affect the chances of being interviewed, and subsequently of being offered the job.

The first column of Table 7 estimates a logit model to determine the effects of an individual's characteristics on the chance of getting an interview. The model includes controls for the company and the logs of the number of applicants and of the number of vacancies as it is plausible that the chance of an interview depends on the number of vacancies relative to the number of applicants. The estimates suggest that age and sex are unimportant in determining the chances of an interview (we did experiment with a non-linear functional form for age but found no effect). However previous relevant experience and being in employment are important in determining the chances of an interview as (more marginally) is having previous experience in the company. The number of applicants and the number of vacancies also have a powerful impact on the chances of being interviewed. The fact that the coefficients on these variables are opposite in sign and of very similar magnitude suggests that it is the ratio of the number of vacancies to the number of applicants that is important. 
This last result suggests that competition for jobs is important in determining the chances of getting an interview. We might therefore expect that it is not just one's personal characteristics that are important in securing an interview but characteristics relative to those of other applicants. The second column takes one approach to this, by including a fixed effect for each vacancy event (as the fixed effect is one way of controlling for the characteristics of the applicant pool). The sample size falls as the logit model cannot be estimated for those vacancies for which everyone is interviewed. The results confirm that those applicants currently employed and with relevant experience are more likely to be offered an interview. This fixed effect specification is rather crude and expensive in terms of degrees of freedom, so the third column of Table 7 estimates a more parsimonious specification in which the average characteristics of the applicant pool are included as additional regressors. These results confirm that being in employment, having relevant experience and having previously worked for the company are important in determining the chance of an interview. In fact one can accept the hypothesis that the coefficients on the individual's characteristics are equal and opposite to those on the averages - these results are reported in the fourth column.

The managers were also asked for the main reason for not interviewing individuals (Table 8). The answers were not constrained so this table is the result of collating similar answers while there is an element of judgement in doing this, it has little impact on the general conclusions. Lack of experience is the most commonly mentioned factor, followed by age, general impression and attitude. With the exception of age, this is in line with our earlier findings if it's recognised that general impression and attitude are correlated with current employment status.

Not all applicants whom the employer wanted to interview actually turned up: $8 \%$ were no-shows. The fifth column of Table 7 considers the determinants of who did not show. We included only individual characteristics as it is not plausible that an individual applicant knows the composition of the applicant pool (none of these variables is significant when included). As can be seen, none of the estimated coefficients is significantly different from zero, though those currently in employment are marginally less likely to turn up.

Once the applicant has been interviewed, the employer needs to decide whether to make an offer. The sixth column of Table 7 presents the results of a logit model for whether the employer makes an offer conditional on inviting to an interview and the worker turning up for it. None of the characteristics' variables are now significant, but the ratio of the number of applicants to vacancies remains very important. This remains true when we include the average characteristics among those interviewed and the numbers interviewed, as reported in the seventh column. This suggests that, once an individual has got to an interview other factors, not wellcaptured by our crude measures of personal characteristics, play the most important role in getting an offer. This is confirmed by the second column of Table 8, which shows that personal habits are now more important, as are issues about the exact hours that the individual can work.

These results suggest (perhaps unsurprisingly) that employers use 'objective' criteria like experience, age and work history when selecting for interview but then rely more on their impression of candidates. Table 8 also shows that it is sometimes the case that the worker is rejecting the employer, or that the worker and employer fail to find a mutually acceptable match, notably over hours worked.

\section{Conclusions}

In this paper we have investigated the process by which vacancies are filled in relatively lowwage segments of the British labour market. The questions addressed in this paper have received 
little attention in the literature. Our conclusions, necessarily tentative because they are based on a small and specific dataset, are, therefore of some interest.

The main findings are that these vacancies have a relatively small number of applicants (under three on average). The number is influenced by the wage offered by the job and non-wage aspects of the job, notably the location of the workplace. However, virtually all the vacancies are filled eventually so that the main impact of the number of applicants is that the employer has a wider choice to choose the 'best' worker. In selecting workers for interview, employers are likely to reject those not currently in employment or lacking relevant work experience but, conditional on being interviewed, such workers are not at any further disadvantage in the selection procedure.

In terms of our understanding of labour markets, these results suggest that these vacancies are not overwhelmed with applicants. Models like efficiency wages which 'explain' unemployment in terms of wages being a long way above reservation wages may be rather wide of the mark (though this should not be taken to mean that efficiency wages are irrelevant in all parts of the labour market). The results also suggest that employers do have the ability to influence the number of applicants through the terms and conditions of employment. 
Table 1

The Response Rate

\begin{tabular}{ccccc}
\hline company & branch & $\begin{array}{c}\text { number of recruits } \\
\text { (payroll records) }\end{array}$ & $\begin{array}{c}\text { number of offers } \\
\text { made in } \\
\text { vacancy sample }\end{array}$ & percentage \\
\hline hotel & 1 & 52 & 42 & 81 \\
hotel & 2 & 23 & 10 & 43 \\
hotel & 3 & 32 & 22 & 69 \\
hotel & 4 & 14 & 5 & 35 \\
hotel & 5 & 30 & 32 & 107 \\
manufacturer & 1 & 33 & 34 & 103 \\
restaurant & 1 & 12 & 11 & 92 \\
restaurant & 2 & 8 & 15 & 126 \\
supermarket & 1 & 77 & 31 & 40 \\
supermarket & 2 & 49 & 62 & 126 \\
supermarket & 3 & 11 & 11 & 36 \\
supermarket & 4 & 17 & 6 & 78 \\
total & & 358 & 281 & \\
\hline
\end{tabular}

Notes: 1 . There is no data for the leisure company and some branches of some others: this is where the payroll data was not provided.

2. The number of recruits is computed by taking all the recruits from the payroll data between the earliest and latest dates mentioned in the vacancy statistics. It is possible to have a percentage more than $100 \%$ because the start dates are not always reported in the vacancy data so could lie outside the sample period from the payroll data. In addition not all offers made are probably accepted. 
Table 2

Descriptive Statistics

\begin{tabular}{|c|c|c|c|}
\hline variable & $\begin{array}{c}\text { number of } \\
\text { observations }\end{array}$ & mean & standard deviation \\
\hline & \multicolumn{3}{|c|}{ Characteristics of the Job } \\
\hline starting hourly wage & 113 & 3.53 & 0.65 \\
\hline starting wages vary? & 118 & 0.15 & 0.36 \\
\hline self-reported relative wage & 118 & 3.04 & 1.03 \\
\hline wage below average & 118 & 0.3 & 0.46 \\
\hline wage above average & 118 & 0.27 & 0.45 \\
\hline weeks until pay increase & 110 & 21.3 & 14.2 \\
\hline size of pay increase (\%) & 106 & 5.7 & 3.1 \\
\hline tips & 105 & 0.43 & 0.5 \\
\hline bonuses & 101 & 0.21 & 0.41 \\
\hline overtime available & 99 & 0.73 & 0.45 \\
\hline central location & 118 & 0.41 & 0.49 \\
\hline accessible by public transport & 118 & 0.76 & 0.43 \\
\hline help with transport & 118 & 0.3 & 0.46 \\
\hline \multirow[t]{2}{*}{ specialist job } & 118 & 0.08 & 0.28 \\
\hline & \multicolumn{3}{|c|}{ Recruitment Methods } \\
\hline job centre & 117 & 0.59 & 0.49 \\
\hline newspaper advert & 118 & 0.35 & 0.48 \\
\hline private agency & 117 & 0.03 & 0.16 \\
\hline existing staff & 117 & 0.61 & 0.49 \\
\hline direct approach & 116 & 0.33 & 0.47 \\
\hline
\end{tabular}


Table 2 (continued)

Descriptive Statistics

\begin{tabular}{ccccc}
\hline variable & number of observations & mean & standard deviation \\
\hline & \multicolumn{3}{c}{ Outcomes } \\
\hline number of vacancies & 118 & $\mathbf{2 . 8 8}$ & 2.97 \\
number of applicants & 118 & $\mathbf{7 . 6 4}$ & 11.23 \\
number of interviews & 110 & $\mathbf{4 . 1 4}$ & 4.52 \\
number of offers & 116 & $\mathbf{2 . 4 9}$ & 3.08 \\
\hline \multicolumn{2}{c}{ average age } & $660^{*}$ & 25.4 & 10.3 \\
proportion female & $660^{*}$ & 0.59 & 0.49 \\
$\begin{array}{c}\text { proportion } \\
\text { with experience }\end{array}$ & $660^{*}$ & 0.42 & 0.49 \\
$\begin{array}{c}\text { proportion previously } \\
\text { worked for company } \\
\text { proportion currently } \\
\text { in employment }\end{array}$ & $660^{*}$ & 0.07 & 0.25 \\
\hline
\end{tabular}

Notes: 1. An asterisk on the number of observations indicates that we are using data on individual job applicants. The absence of an asterisk indicates that the variable refers to the number of vacancy events. 
Table 3

Correlations of Self-Reported and 'Objective' Relative Pay

\begin{tabular}{ccccc}
\hline & \multicolumn{2}{c}{ reported competitor's wage } & \multicolumn{2}{c}{ NES measure of alternative wage } \\
\hline $\begin{array}{c}\text { self-reported } \\
\text { relative wage }\end{array}$ & log relative wage & $\begin{array}{c}\text { number of } \\
\text { observations }\end{array}$ & log relative wage & $\begin{array}{c}\text { number of } \\
\text { observations }\end{array}$ \\
lot above average & 0.26 & 1 & -0.36 & 1 \\
& $(0)$ & 16 & -0.26 & 36 \\
above average & 0.15 & & $(0.25)$ & \\
& $(0.25)$ & 24 & -0.32 & \\
average & 0.01 & & $(0.18)$ & 23 \\
& $(0.06)$ & 20 & -0.26 & 12 \\
below average & -0.01 & & $(0.15)$ & \\
lot below average & $(0.12)$ & 0 & -0.38 & $(0)$ \\
\end{tabular}

Notes: 1. Standard errors are reported in parentheses. 
Table 4: Determinants of the Number of Applicants

\begin{tabular}{|c|c|c|c|c|c|c|c|c|}
\hline $\begin{array}{l}\text { dependent } \\
\text { variable }\end{array}$ & $\begin{array}{l}\text { number of } \\
\text { applicants }\end{array}$ & $\begin{array}{l}\text { number of } \\
\text { applicants }\end{array}$ & $\begin{array}{l}\text { number of } \\
\text { applicants }\end{array}$ & $\begin{array}{l}\text { number of } \\
\text { applicants }\end{array}$ & $\begin{array}{l}\text { number of } \\
\text { applicants }\end{array}$ & $\begin{array}{l}\text { number of } \\
\text { applicants }\end{array}$ & $\begin{array}{l}\text { number of } \\
\text { employed } \\
\text { applicants }\end{array}$ & $\begin{array}{l}\text { number of } \\
\text { unemployed } \\
\text { applicants }\end{array}$ \\
\hline $\begin{array}{l}\text { central } \\
\text { location }\end{array}$ & $\begin{array}{c}0.55 \\
(0.32)\end{array}$ & $\begin{array}{c}0.66 \\
(0.27)\end{array}$ & $\begin{array}{c}0.78 \\
(0.22)\end{array}$ & $\begin{array}{c}0.71 \\
(0.31)\end{array}$ & $\begin{array}{c}0.77 \\
(0.21)\end{array}$ & $\begin{array}{c}0.42 \\
(0.35)\end{array}$ & $\begin{array}{l}1.30 \\
(0.39)\end{array}$ & $\begin{array}{c}0.33 \\
(0.27)\end{array}$ \\
\hline$\underset{\text { transport }}{\text { public }}$ & $\begin{array}{c}1.12 \\
(0.36)\end{array}$ & $\begin{array}{c}0.92 \\
(0.33)\end{array}$ & $\begin{array}{c}0.55 \\
(0.28)\end{array}$ & $\begin{array}{c}0.61 \\
(0.29)\end{array}$ & $\begin{array}{c}0.83 \\
(0.28)\end{array}$ & $\begin{array}{c}0.77 \\
(0.37)\end{array}$ & $\begin{array}{l}-0.07 \\
(0.80)\end{array}$ & $\begin{array}{l}1.76 \\
(0.50)\end{array}$ \\
\hline $\begin{array}{l}\text { help with } \\
\text { transport }\end{array}$ & $\begin{array}{l}-0.01 \\
(0.34)\end{array}$ & & & & & & & \\
\hline $\begin{array}{c}\text { wage } \\
\text { performance }\end{array}$ & $\begin{array}{c}0.38 \\
(0.22)\end{array}$ & $\begin{array}{c}0.50 \\
(0.19)\end{array}$ & $\begin{array}{c}0.35 \\
(0.15)\end{array}$ & & $\begin{array}{c}0.25 \\
(0.15)\end{array}$ & $\begin{array}{c}0.36 \\
(0.16)\end{array}$ & $\begin{array}{c}0.18 \\
(0.60)\end{array}$ & $\begin{array}{c}0.22 \\
(0.21)\end{array}$ \\
\hline $\begin{array}{l}\text { wage above } \\
\text { average }\end{array}$ & & & & $\begin{array}{c}0.28 \\
(0.34)\end{array}$ & & & & \\
\hline $\begin{array}{l}\text { wage below } \\
\text { average }\end{array}$ & & & & $\begin{array}{l}-0.60 \\
(0.33)\end{array}$ & & & & \\
\hline wages vary & & & & & $\begin{array}{c}0.70 \\
(0.19)\end{array}$ & $\begin{array}{c}0.77 \\
(0.27)\end{array}$ & $\begin{array}{c}0.07 \\
(0.38)\end{array}$ & $\begin{array}{l}1.07 \\
(0.27)\end{array}$ \\
\hline $\begin{array}{l}\text { fringe } \\
\text { benefits }\end{array}$ & & & & & & $\begin{array}{l}-0.07 \\
(0.27)\end{array}$ & & \\
\hline $\begin{array}{l}\text { time to pay } \\
\text { increase }\end{array}$ & & & & & & $\begin{array}{c}0.002 \\
(0.010)\end{array}$ & & \\
\hline $\begin{array}{l}\text { size of pay } \\
\text { increase }\end{array}$ & & & & & & $\begin{array}{l}0.008 \\
(0.06)\end{array}$ & & \\
\hline job centre & $\begin{array}{c}0.15 \\
(0.24)\end{array}$ & & & & & & & \\
\hline $\begin{array}{l}\text { advert in } \\
\text { newspaper }\end{array}$ & $\begin{array}{c}0.41 \\
(0.32)\end{array}$ & $\begin{array}{c}0.37 \\
(0.28)\end{array}$ & $\begin{array}{l}-0.14 \\
(0.17)\end{array}$ & $\begin{array}{l}-0.07 \\
(0.23)\end{array}$ & $\begin{array}{l}-0.21 \\
(0.23)\end{array}$ & $\begin{array}{l}-0.42 \\
(0.26)\end{array}$ & $\begin{array}{l}-0.20 \\
(0.44)\end{array}$ & $\begin{array}{c}0.40 \\
(0.35)\end{array}$ \\
\hline $\begin{array}{l}\text { private } \\
\text { agency }\end{array}$ & $\begin{array}{l}-0.01 \\
(0.60)\end{array}$ & & & & & & & \\
\hline $\begin{array}{l}\text { existing staff } \\
\text { notified }\end{array}$ & $\begin{array}{c}0.12 \\
(0.29)\end{array}$ & & & & & & & \\
\hline $\begin{array}{l}\text { approach to } \\
\text { individuals }\end{array}$ & $\begin{array}{l}-0.39 \\
(0.20)\end{array}$ & $\begin{array}{l}-0.40 \\
(0.19)\end{array}$ & $\begin{array}{l}-0.35 \\
(0.15)\end{array}$ & $\begin{array}{l}-0.23 \\
(0.17)\end{array}$ & $\begin{array}{l}-0.15 \\
(0.16)\end{array}$ & $\begin{array}{l}-0.07 \\
(0.17)\end{array}$ & $\begin{array}{l}-0.04 \\
(0.31)\end{array}$ & $\begin{array}{l}-0.18 \\
(0.21)\end{array}$ \\
\hline walk-ins & $\begin{array}{l}-0.30 \\
(0.24)\end{array}$ & & & & & & & \\
\hline $\begin{array}{l}\text { specialist } \\
\text { job }\end{array}$ & $\begin{array}{l}-0.70 \\
(0.36)\end{array}$ & $\begin{array}{l}-0.59 \\
(0.32)\end{array}$ & $\begin{array}{l}-0.32 \\
(0.27)\end{array}$ & $\begin{array}{l}-0.30 \\
(0.27)\end{array}$ & $\begin{array}{l}-0.33 \\
(0.25)\end{array}$ & $\begin{array}{l}-0.14 \\
(0.30)\end{array}$ & $\begin{array}{c}0.09 \\
(0.40)\end{array}$ & $\begin{array}{l}-1.03 \\
(0.37)\end{array}$ \\
\hline $\begin{array}{c}\ln (\text { no of } \\
\text { vacancies })\end{array}$ & & & $\begin{array}{c}0.67 \\
(0.09)\end{array}$ & $\begin{array}{c}0.66 \\
(0.09)\end{array}$ & $\begin{array}{c}0.66 \\
(0.19)\end{array}$ & $\begin{array}{c}0.54 \\
(0.10)\end{array}$ & $\begin{array}{c}0.25 \\
(0.16)\end{array}$ & $\begin{array}{c}0.83 \\
(0.11)\end{array}$ \\
\hline $\begin{array}{c}\text { number of } \\
\text { obs }\end{array}$ & 116 & 116 & 116 & 116 & 116 & 86 & 100 & 100 \\
\hline $\ln ($ alpha) & $\begin{array}{l}-0.70 \\
(0.17)\end{array}$ & $\begin{array}{l}-0.68 \\
(0.17)\end{array}$ & $\begin{array}{l}-1.29 \\
(0.21)\end{array}$ & $\begin{array}{l}-1.30 \\
(0.21)\end{array}$ & $\begin{array}{l}-1.54 \\
(0.24)\end{array}$ & $\begin{array}{l}-1.99 \\
(0.39)\end{array}$ & $\begin{array}{l}-0.37 \\
(0.26)\end{array}$ & $\begin{array}{l}-1.33 \\
(0.31)\end{array}$ \\
\hline $\begin{array}{l}\log \\
\text { likelihood }\end{array}$ & -317.5 & -318.7 & -294.2 & -294 & -287.9 & -192 & -184 & -208.3 \\
\hline
\end{tabular}


Notes 1. All the estimates refer to an estimate of the negative binomial model. Each equation also includes a constant, company and regional dummies. Standard errors are in parentheses.

\section{Table 5}

\section{Determinants of the Quality of Applicants}

\begin{tabular}{|c|c|c|c|c|c|}
\hline $\begin{array}{l}\text { dependent } \\
\text { variable }\end{array}$ & $\begin{array}{l}\text { proportion } \\
\text { experienced }\end{array}$ & $\begin{array}{l}\text { proportion } \\
\text { currently } \\
\text { employed }\end{array}$ & $\begin{array}{l}\text { proportion } \\
\text { previously } \\
\text { employed in } \\
\text { company }\end{array}$ & $\begin{array}{l}\text { proportion } \\
\text { female }\end{array}$ & $\begin{array}{c}\text { average } \\
\text { age }\end{array}$ \\
\hline central location & $\begin{array}{c}0.08 \\
(0.11)\end{array}$ & $\begin{array}{c}0.13 \\
(0.11)\end{array}$ & $\begin{array}{c}0.18 \\
(0.08)\end{array}$ & $\begin{array}{c}0.05 \\
(0.13)\end{array}$ & $\begin{array}{c}6.93 \\
(3.42)\end{array}$ \\
\hline public transport & $\begin{array}{c}0.23 \\
(0.17)\end{array}$ & $\begin{array}{l}-0.15 \\
(0.18)\end{array}$ & $\begin{array}{l}-0.01 \\
(0.10)\end{array}$ & $\begin{array}{l}-0.48 \\
(0.18)\end{array}$ & $\begin{array}{l}-11.28 \\
(4.75)\end{array}$ \\
\hline help with transport & $\begin{array}{l}-0.13 \\
(0.15)\end{array}$ & $\begin{array}{l}-0.15 \\
(0.20)\end{array}$ & $\begin{array}{l}-0.16 \\
(0.12)\end{array}$ & $\begin{array}{l}-0.36 \\
(0.16)\end{array}$ & $\begin{array}{c}0.31 \\
(0.12)\end{array}$ \\
\hline wage performance & $\begin{array}{l}-0.03 \\
(0.07)\end{array}$ & $\begin{array}{l}0.004 \\
(0.09)\end{array}$ & $\begin{array}{c}0.05 \\
(0.07)\end{array}$ & $\begin{array}{l}-0.08 \\
(0.09)\end{array}$ & $\begin{array}{l}-0.20 \\
(0.10)\end{array}$ \\
\hline wages vary & $\begin{array}{c}0.23 \\
(0.13)\end{array}$ & $\begin{array}{l}-0.17 \\
(0.14)\end{array}$ & $\begin{array}{c}0.10 \\
(0.06)\end{array}$ & $\begin{array}{l}-0.21 \\
(0.12)\end{array}$ & $\begin{array}{l}-4.63 \\
(2.39)\end{array}$ \\
\hline job centre & $\begin{array}{l}-0.24 \\
(0.09)\end{array}$ & $\begin{array}{c}0.04 \\
(0.11)\end{array}$ & $\begin{array}{l}-0.22 \\
(0.08)\end{array}$ & $\begin{array}{c}0.03 \\
(0.10)\end{array}$ & $\begin{array}{l}-4.03 \\
(2.12)\end{array}$ \\
\hline advert in newspaper & $\begin{array}{c}0.07 \\
(0.13)\end{array}$ & $\begin{array}{l}-0.12 \\
(0.15)\end{array}$ & $\begin{array}{l}-0.23 \\
(0.08)\end{array}$ & $\begin{array}{l}-0.16 \\
(0.14)\end{array}$ & $\begin{array}{l}-2.18 \\
(3.38)\end{array}$ \\
\hline private agency & $\begin{array}{l}-0.09 \\
(0.18)\end{array}$ & $\begin{array}{l}-0.30 \\
(0.16)\end{array}$ & $\begin{array}{c}0.01 \\
(0.12)\end{array}$ & $\begin{array}{c}0.01 \\
(0.27)\end{array}$ & $\begin{array}{c}2.16 \\
(3.81)\end{array}$ \\
\hline existing staff notified & $\begin{array}{l}0.004 \\
(0.09)\end{array}$ & $\begin{array}{l}-0.14 \\
(0.10)\end{array}$ & $\begin{array}{l}-0.05 \\
(0.07)\end{array}$ & $\begin{array}{c}0.07 \\
(0.14)\end{array}$ & $\begin{array}{c}2.65 \\
(3.37)\end{array}$ \\
\hline approach to individuals & $\begin{array}{c}0.02 \\
(0.08)\end{array}$ & $\begin{array}{c}0.02 \\
(0.09)\end{array}$ & $\begin{array}{c}0.08 \\
(0.07)\end{array}$ & $\begin{array}{l}-0.04 \\
(0.10)\end{array}$ & $\begin{array}{l}-2.51 \\
(1.91)\end{array}$ \\
\hline walk-ins & $\begin{array}{l}-0.10 \\
(0.07)\end{array}$ & $\begin{array}{c}0.07 \\
(0.09)\end{array}$ & $\begin{array}{l}-0.03 \\
(0.04)\end{array}$ & $\begin{array}{c}0.01 \\
(0.10)\end{array}$ & $\begin{array}{l}-0.53 \\
(2.32)\end{array}$ \\
\hline specialist job & $\begin{array}{l}-0.70 \\
(0.36)\end{array}$ & $\begin{array}{c}0.22 \\
(0.16)\end{array}$ & $\begin{array}{c}0.11 \\
(0.11)\end{array}$ & $\begin{array}{c}0.04 \\
(0.16)\end{array}$ & $\begin{array}{c}-0.34 \\
(3.19)\end{array}$ \\
\hline $\ln$ (no of vacancies) & $\begin{array}{l}-0.05 \\
(0.05)\end{array}$ & $\begin{array}{l}-0.13 \\
(0.06)\end{array}$ & $\begin{array}{l}-0.006 \\
(0.02)\end{array}$ & $\begin{array}{c}0.09 \\
(0.05)\end{array}$ & $\begin{array}{l}-1.77 \\
(0.94)\end{array}$ \\
\hline number of observations & 100 & 100 & 100 & 100 & 100 \\
\hline $\mathrm{R}^{2}$ & 0.42 & 0.38 & 0.38 & 0.29 & 0.34 \\
\hline
\end{tabular}

Notes 1. All the estimates refer to an estimate of a linear regression model. Each equation also includes a constant, company and regional dummies. Heteroscedastic-consistent standard errors are in parentheses. 
Table 6

Determinants of the Number of Interviews and Offers

\begin{tabular}{|c|c|c|c|c|}
\hline dependent variable & $\begin{array}{l}\text { number of } \\
\text { interviews }\end{array}$ & $\begin{array}{c}\text { number of } \\
\text { offers }\end{array}$ & $\begin{array}{c}\text { number } \\
\text { of } \\
\text { interview } \\
\mathrm{s}\end{array}$ & $\begin{array}{c}\text { number of } \\
\text { offers }\end{array}$ \\
\hline central location & $\begin{array}{c}0.24 \\
(0.20)\end{array}$ & $\begin{array}{c}0.01 \\
(0.25)\end{array}$ & & \\
\hline public transport & $\begin{array}{c}0.45 \\
(0.26)\end{array}$ & $\begin{array}{c}0.06 \\
(0.29)\end{array}$ & & \\
\hline wage performance & $\begin{array}{c}0.09 \\
(0.14)\end{array}$ & $\begin{array}{l}-0.06 \\
(0.16)\end{array}$ & & \\
\hline wages vary & $\begin{array}{c}0.19 \\
(0.19)\end{array}$ & $\begin{array}{c}0.24 \\
(0.20)\end{array}$ & & \\
\hline advert in newspaper & $\begin{array}{c}0.43 \\
(0.25)\end{array}$ & $\begin{array}{c}0.20 \\
(0.33)\end{array}$ & & \\
\hline approach to individuals & $\begin{array}{r}-0.004 \\
(0.14)\end{array}$ & $\begin{array}{l}0.002 \\
(0.16)\end{array}$ & & \\
\hline specialist job & $\begin{array}{l}-0.12 \\
(0.23)\end{array}$ & $\begin{array}{l}-0.01 \\
(0.30)\end{array}$ & $\begin{array}{c}0.09 \\
(0.21)\end{array}$ & $\begin{array}{c}0.20 \\
(0.29)\end{array}$ \\
\hline $\ln$ (no of vacancies) & $\begin{array}{c}0.59 \\
(0.08)\end{array}$ & $\begin{array}{c}0.96 \\
(0.09)\end{array}$ & $\begin{array}{l}0.31 \\
(0.07)\end{array}$ & $\begin{array}{c}0.83 \\
(0.10)\end{array}$ \\
\hline $\ln$ ( no of applications) & & & $\begin{array}{c}0.45 \\
(0.07)\end{array}$ & $\begin{array}{c}0.19 \\
(0.09)\end{array}$ \\
\hline $\begin{array}{l}\text { proportion of applicants } \\
\text { employed }\end{array}$ & & & $\begin{array}{c}0.08 \\
(0.19)\end{array}$ & $\begin{array}{l}-0.36 \\
(0.24)\end{array}$ \\
\hline $\begin{array}{l}\text { proportion of applicants } \\
\text { experienced }\end{array}$ & & & $\begin{array}{c}0.17 \\
(0.19)\end{array}$ & $\begin{array}{c}0.30 \\
(0.24)\end{array}$ \\
\hline $\begin{array}{l}\text { proportion of applicants } \\
\text { previous employee }\end{array}$ & & & $\begin{array}{l}-0.66 \\
(0.32)\end{array}$ & $\begin{array}{l}-0.06 \\
(0.37)\end{array}$ \\
\hline proportion of applicants female & & & $\begin{array}{c}0.09 \\
(0.15)\end{array}$ & $\begin{array}{c}0.22 \\
(0.20)\end{array}$ \\
\hline average age of applicants & & & $\begin{array}{l}0.0001 \\
(0.007)\end{array}$ & $\begin{array}{l}-0.005 \\
(0.010)\end{array}$ \\
\hline number of observations & 108 & 114 & 127 & 127 \\
\hline $\ln ($ alpha $)$ & $\begin{array}{l}-2.51 \\
(0.47)\end{array}$ & $\begin{array}{l}-14.11 \\
(53.4)\end{array}$ & $\begin{array}{l}-4.48 \\
(2.30)\end{array}$ & $\begin{array}{l}-17.6 \\
(60.2)\end{array}$ \\
\hline log likelihood & -214.5 & -154.7 & -239.7 & -180.71 \\
\hline
\end{tabular}


Notes: 1. All the estimates refer to an estimate of the negative binomial model. Each equation also includes a constant, company and regional dummies. Standard errors are in parentheses.

Table 7

The Selection Process

\begin{tabular}{|c|c|c|c|c|c|c|c|}
\hline & (1) & (2) & (3) & (4) & (5) & (6) & (7) \\
\hline $\begin{array}{l}\text { dependent } \\
\text { variable }\end{array}$ & $\begin{array}{l}\text { selected } \\
\text { for } \\
\text { interview }\end{array}$ & $\begin{array}{l}\text { selected for } \\
\text { interview }\end{array}$ & $\begin{array}{l}\text { selected } \\
\quad \text { for } \\
\text { interview }\end{array}$ & $\begin{array}{l}\text { selected } \\
\text { for } \\
\text { interview }\end{array}$ & $\begin{array}{l}\text { turned up for } \\
\text { interview }\end{array}$ & offered job & offered job \\
\hline sample & $\begin{array}{c}\text { all } \\
\text { applicants }\end{array}$ & $\begin{array}{c}\text { all } \\
\text { applicants }\end{array}$ & $\begin{array}{c}\text { all } \\
\text { applicants }\end{array}$ & $\begin{array}{c}\text { all } \\
\text { applicants }\end{array}$ & $\begin{array}{l}\text { selected for } \\
\text { interview }\end{array}$ & $\begin{array}{c}\text { all } \\
\text { interviewed }\end{array}$ & $\begin{array}{c}\text { all } \\
\text { interviewed }\end{array}$ \\
\hline age & $\begin{array}{c}0.002 \\
(0.010)\end{array}$ & $\begin{array}{c}0.012 \\
(0.015)\end{array}$ & $\begin{array}{c}0.011 \\
(0.014)\end{array}$ & & $\begin{array}{l}-0.016 \\
(0.020)\end{array}$ & $\begin{array}{l}-0.012 \\
(0.017)\end{array}$ & $\begin{array}{l}-0.002 \\
(0.018)\end{array}$ \\
\hline average age & & & $\begin{array}{l}-0.009 \\
(0.023)\end{array}$ & & & $\begin{array}{c}0.034 \\
(0.026)\end{array}$ & $\begin{array}{c}0.014 \\
(0.025)\end{array}$ \\
\hline female & $\begin{array}{c}0.045 \\
(0.207)\end{array}$ & $\begin{array}{l}-0.068 \\
(0.283)\end{array}$ & $\begin{array}{c}0.000 \\
(0.256)\end{array}$ & & $\begin{array}{l}-0.384 \\
(0.837)\end{array}$ & $\begin{array}{l}-0.347 \\
(0.349)\end{array}$ & $\begin{array}{l}-0.423 \\
(0.367)\end{array}$ \\
\hline $\begin{array}{l}\text { proportion } \\
\text { female }\end{array}$ & & & $\begin{array}{l}0.097 \\
(0.45\end{array}$ & & & $\begin{array}{c}0.463 \\
(0.527)\end{array}$ & $\begin{array}{c}0.394 \\
(0.507)\end{array}$ \\
\hline employed & $\begin{array}{c}0.426 \\
(0.218)\end{array}$ & $\begin{array}{c}0.796 \\
(0.283)\end{array}$ & $\begin{array}{c}0.581 \\
(0.252)\end{array}$ & $\begin{array}{c}0.570 \\
(0.247)\end{array}$ & $\begin{array}{c}0.859 \\
(0.502)\end{array}$ & $\begin{array}{l}-0.166 \\
(0.308)\end{array}$ & $\begin{array}{l}-0.304 \\
(0.325)\end{array}$ \\
\hline $\begin{array}{l}\text { proportion } \\
\text { employed }\end{array}$ & & & $\begin{array}{l}-0.268 \\
(0.540)\end{array}$ & -0.57 & & $\begin{array}{l}-0.848 \\
(0.597)\end{array}$ & $\begin{array}{l}-0.237 \\
(0.583)\end{array}$ \\
\hline experienced & $\begin{array}{c}0.872 \\
(0.225)\end{array}$ & $\begin{array}{c}1.31 \\
(0.282)\end{array}$ & $\begin{array}{c}1.066 \\
(0.253)\end{array}$ & $\begin{array}{c}1.038 \\
(0.247)\end{array}$ & $\begin{array}{c}0.043 \\
(0.458)\end{array}$ & $\begin{array}{c}0.350 \\
(0.315)\end{array}$ & $\begin{array}{c}0.407 \\
(0.337)\end{array}$ \\
\hline $\begin{array}{l}\text { proportion } \\
\text { experienced }\end{array}$ & & & $\begin{array}{l}-0.806 \\
(0.571)\end{array}$ & -1.038 & & $\begin{array}{l}-0.362 \\
(0.627)\end{array}$ & $\begin{array}{l}-0.331 \\
(0.582)\end{array}$ \\
\hline $\begin{array}{l}\text { company } \\
\text { experience }\end{array}$ & $\begin{array}{c}0.666 \\
(0.533)\end{array}$ & $\begin{array}{c}1.928 \\
(0.731)\end{array}$ & $\begin{array}{c}1.369 \\
(0.640)\end{array}$ & $\begin{array}{c}1.364 \\
(0.630)\end{array}$ & see notes & $\begin{array}{c}0.475 \\
(0.618)\end{array}$ & $\begin{array}{c}0.132 \\
(0.628)\end{array}$ \\
\hline $\begin{array}{l}\text { proportion } \\
\text { with company } \\
\text { experience }\end{array}$ & & & $\begin{array}{l}-2.011 \\
(0.967)\end{array}$ & -1.364 & & $\begin{array}{c}0.098 \\
(1.071)\end{array}$ & $\begin{array}{c}0.757 \\
(0.954)\end{array}$ \\
\hline $\begin{array}{l}\ln \text { (number of } \\
\text { applicants) }\end{array}$ & $\begin{array}{c}-1.042 \\
(0.141)\end{array}$ & & $\begin{array}{l}-1.154 \\
(0.154)\end{array}$ & $\begin{array}{l}-1.128 \\
(0.141)\end{array}$ & $\begin{array}{l}-0.277 \\
(0.263)\end{array}$ & $\begin{array}{c}-1.03 \\
(0.174)\end{array}$ & $\begin{array}{l}-1.509 \\
(0.222)\end{array}$ \\
\hline $\begin{array}{l}\ln \text { (number of } \\
\text { vacancies) }\end{array}$ & $\begin{array}{c}1.057 \\
(0.165)\end{array}$ & & $\begin{array}{c}1.068 \\
(0.171)\end{array}$ & $\begin{array}{c}1.027 \\
(0.161)\end{array}$ & $\begin{array}{c}0.324 \\
(0.305)\end{array}$ & $\begin{array}{c}1.426 \\
(0.204)\end{array}$ & $\begin{array}{c}1.888 \\
(0.248)\end{array}$ \\
\hline $\begin{array}{c}\text { number of } \\
\text { observations }\end{array}$ & 658 & 398 & 658 & 671 & 411 & 407 & 407 \\
\hline log-likelihood & -309.8 & -209.1 & -305.1 & -311.6 & -89.7 & -210 & -204.9 \\
\hline
\end{tabular}

Notes: 1. Standard errors in parentheses.

2. In column (5) there are no estimates for those who had previously worked for the company as all of these workers were interviewed. 
3. The difference between the sixth and seventh columns is that in the sixth column the average characteristics refer to those of the applicant pool as a whole whereas in the seventh column it is the characteristics of those interviewed. The number of applicants in the final column is the number interviewed. 
Table 8

Reasons Given by Employers for Applicants Leaving Selection Process

\begin{tabular}{|c|c|c|c|c|}
\hline & \multicolumn{2}{|c|}{ Reason for Not Interviewing } & \multicolumn{2}{|c|}{ Reason for Rejecting After Interview } \\
\hline & no. of observations & percentage & no. of observations & percentage \\
\hline lack of experience & 41 & 23 & 22 & 13 \\
\hline age & 26 & 14 & 3 & 2 \\
\hline bad work history & 11 & 6 & 3 & 2 \\
\hline $\begin{array}{l}\text { bad reference } \\
\text { or impression }\end{array}$ & 22 & 12 & 61 & 35 \\
\hline poor health record & 5 & 3 & 1 & 1 \\
\hline bad English & 2 & 1 & 2 & 1 \\
\hline failed test set & 23 & 12 & 0 & 0 \\
\hline lived too far away & 4 & 2 & 0 & 0 \\
\hline better candidate & - & - & 20 & 11 \\
\hline $\begin{array}{l}\text { hours wanted } \\
\text { not possible }\end{array}$ & 17 & 9 & 32 & 18 \\
\hline pay too low & 5 & 3 & 8 & 5 \\
\hline got another job & 2 & 1 & 6 & 3 \\
\hline worker not available & 2 & 1 & 0 & 0 \\
\hline $\begin{array}{l}\text { worker gets more } \\
\text { on benefit }\end{array}$ & 0 & 0 & 0 & 0 \\
\hline $\begin{array}{l}\text { insufficient info } \\
\text { on application }\end{array}$ & 10 & 6 & 5 & 3 \\
\hline other & 7 & 4 & 8 & 5 \\
\hline total & 184 & 100 & 175 & 100 \\
\hline
\end{tabular}


Figure 1

Overview of the Recruitment Process

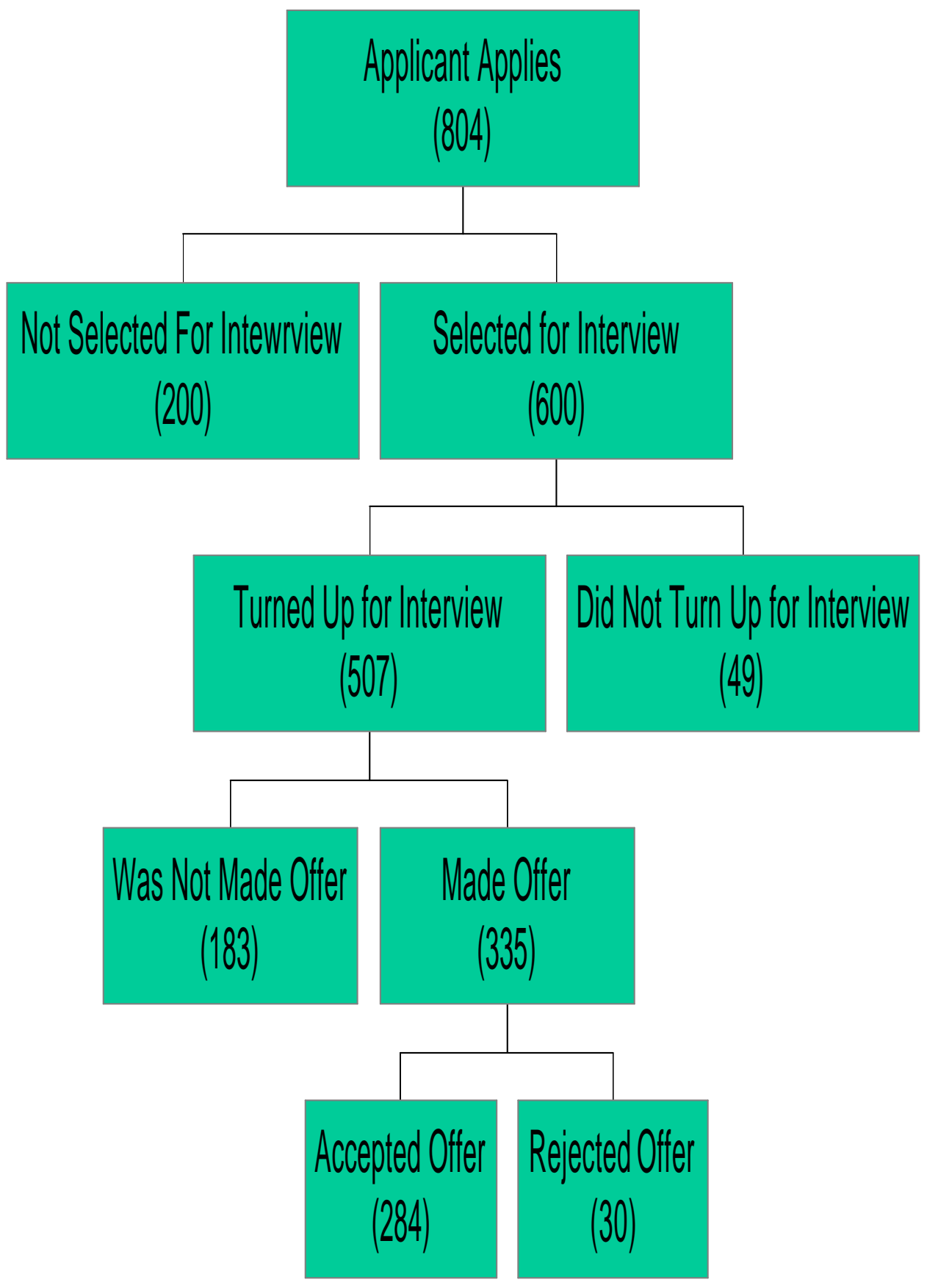

Notes. 1. The numbers in parentheses represent the number of applicants observed at each stage. Where they do not add up to the number listed at the previous stage is because of missing information for some applicants. 


\section{Appendix}

\section{Derivation of Equation (1)}

Consider a short interval of time?, short enough for the probability of more than one individual leaving or joining the pool to be negligible (technically $\mathrm{o}($ ? $)$ ). Denote by $\mathrm{f}_{A}(\mathrm{t})$ the probability of having $A$ potential applicants in the pool at time t. We must have:

$$
f_{A}(t \%) \quad, \quad(1 \& r ? \& A d ?) f_{A}(t) \% r ? f_{A \& l}(t) \% d(A \%) ? f_{A \%}(t)
$$

Now let ? 60 in which case (3) can be written as:

$$
\frac{\mathrm{M}_{A}(t)}{\mathrm{M}}, \quad \&(r \% d d) f_{A}(t) \% r f_{A \& l}(t) \% d(A \% d) f_{A \%}(t)
$$

In a steady-state $\mathrm{f}_{A}(\mathrm{t})$ must be constant in which case we have:

$$
(r \% A d) f_{A} \quad, \quad r f_{A \& l} \% d(A \%) f_{A \%}
$$

which can be interpreted as saying that inflows must equal outflows. Using the definition that $r=\mu d$, we can write (5) as:

$$
(\mu \%) f_{A} \quad, \quad \mu f_{A \& l} \%(A \%) f_{A \%}
$$

By substitution one can confirm that the solution to this difference equation must be of the form $\mathrm{f}_{A}=\mathrm{k} \mu^{A} / A$ ! for some constant $\mathrm{k}$. The constant $\mathrm{k}$ can then be deduced by the fact that, as $\mathrm{f}_{A}$ is a density function we must have:

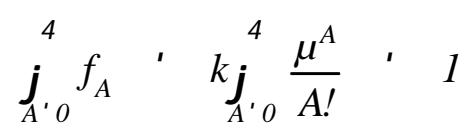

which leads to $\mathrm{k}=\mathrm{e}^{-\mu}$. This gives (1). 


\section{References}

Barron, J. and J. Bishop (1985) "Extensive Search, Intensive Search and Hiring Costs: New Evidence on Employer Hiring Activity”, Economic Inquiry, Vol.23, pp.363-382.

Barron, J., J. Bishop and W. Dunkelberg (1985) "Employer Search: The Interviewing and Hiring of New Employees", Review of Economics and Statistics, Vol.67, pp.43-52.

Beaumont, P. (1978) “The Duration of Registered Vacancies: An Exploratory Exercise”, Scottish Journal of Political Economy, Vol.25, pp.75-97.

Blanchard, O. and P. Diamond (1994) "Ranking, Unemployment Duration, and Wages", Review of Economic Studies, Vol.61, pp.417-34.

Coles, M. and E. Smith (1994) "Marketplaces and Matching”, CEPR Discussion Paper No.1048.

Devine, T. and N. Kiefer (1991) Empirical Labor Economics: The Search Approach, New York: Oxford University Press.

Diamond, P. (1982) “Aggregate Demand Management in Search Equilibrium”, Journal of Political Economy, Vol.90, pp.881-94.

Greene, W. (1997) "Econometric Analysis”, London: Prentice-Hall.

Gregg, P. and B. Petrongolo (1997) "Random or Non-Random Matching? Implications for the Use of the UV Curve as a Measure of Matching Effectiveness", Centre for Economic Performance Discussion Paper No.348, London School of Economics.

Gregg, P. and J. Wadsworth (1996) "Mind the Gap Please? The Changing Nature of Entry Jobs in Britain", Centre for Economic Performance Discussion Paper 303, London School of Economics.

Gregory, M. and R. Jukes (1997) "The Effects of Unemployment on Subsequent Earnings: A Study of British Men, 1984-94”, Department for Education and Employment Working Paper.

Gross, D. and C. Harris (1974) Fundamentals of Queueing Theory, New York: John Wiley.

Holzer, H. (1994) "Job Vacancy Rates in the Firm: An Empirical Analysis", Economica, Vol.61, pp.17-36.

Holzer, H., L. Katz and A. Krueger (1991) "Job Queues and Wages", Quarterly Journal of Economics, Vol.106, pp.739-768.

Layard, R., S. Nickell and R. Jackman (1991) Unemployment: Macroeconomic Performance and the Labour Market, Oxford: Oxford University Press. 
Manning, A. and J. Thomas (1997) “A Simple Test of the Shirking Model”, Centre for Economic Performance Discussion Paper No. 374, London School of Economics.

Meager, N. And H. Metcalf (1987) Recruitment of the Long Term Unemployed, Institute of Manpower Studies: Brighton.

Meager, N. and H. Metcalf (1996) Employers, Recruitment and the Unemployed, Institute of Manpower Studies: Brighton.

National Bureau of Economic Research (1966) The Measurement and Interpretation of Job Vacancies, New York: Columbia University Press.

Pissarides, C. (1990) Equilibrium Unemployment Theory Oxford: Blackwell.

Roper, S. (1988) "Recruitment Methods and Vacancy Duration", Scottish Journal of Political Economy, Vol.35, pp.51-64.

van Ours, J. (1989) “Durations of Dutch Job Vacancies”, de Economist, Vol.137, pp.309-327.

van Ours, J. and G. Ridder (1992) "Vacancies and the Recruitment of New Employees", Journal of Labor Economics, Vol.10, pp.138-155.

van Ours, J. and G. Ridder (1993) "Vacancy Durations: Search or Selection”, Oxford Bulletin of Economics and Statistics, Vol.55, pp.187-198.

van Ours, J. and G. Ridder (1995) "Job Matching and Job Competition: Are Lower Educated Workers at the Back of Job Queues?", European Economic Review; Vol.39, pp.1717-31. 